\title{
John Macintyre, M.D., LL.D.
}

JoHn Macintyre was born in Glasgow in 1857 and graduated at Glasgow Jniversity in 1882. He devoted himself from the first to the study of liryngology and built up a very large practice in that medical speciality. His published articles dealt mainly with the practical aspects of laryngology, and his eminence in the subject is attested by the facts that he was elected to the membership of several Laryngological Societies on the Continent and in America, and that he occupied the Presidential Chair of the British Laryngological Society in 1893 and agair in 1900 .

Another line of work pursued indefatigably by Dr Macintyre, although it was not in the direct line of his speciality, was the application of modern discoveries in electricity to medicine. He was trained in his youth as an electrician, and when, in 1895, Röntgen's discovery of the $\mathrm{X}$-rays was published he threw himself with great enthusiasm into the study of the applications of the discovery in surgical diagnosis. He was a pioneer in this matter, and contributed not a little to the development of radiology in this country. He was generally recognised as a capable and ingenious investigator, and produced some of the earliest radiograms in the form of negative prints. He was the first to realise the importance of the soft tissue shadows in radiograms, and by certain modifications devised by himself in the apparatus and in the procedure he was able to reduce the time of exposure to a fraction of a second. This enabled him to study the movements of parts, and as early as 1896 he was able to demonstrate in the cinematograph the movements of the leg of the frog. He published a number of papers dealing chiefly with the development of the X-ray apparatus, screens, and so forth, and he organised at the Glasgow Royal Infirmary, very shortly after the discovery of the X-rays, a Radiological Department which is believed to have been the second installation of the kind in the world. He was one of the original members, indeed the founder, of the Röntgen Society of London, and one of its early Presidents.

In his early days he was Demonstrator of Anatomy at the Glasgow Royal Infirmary Medical School under Mr Henry E. Clark, and there made an intensive study of the anatomy of the larynx. His description of certain small muscles in connection with the human larynx, named 
"hyo-epiglottidean," has received a place in textbooks of descriptive anatomy.

The Senate of the University of Glasgow conferred upon him the degree of LL.D. in 1920 in recognition of his eminent services to medicine.

He was elected a Fellow of the Society in 1895, and died on 29th October 1928.

T. H. B. 